\title{
Palaeoslopes of Weichselian sand-bed braided rivers in the Torun Basin (Poland): results of a palaeohydraulic analysis
}

\author{
Piotr Weckwerth
}

Institute of Geography, Nicolas Copernicus University, ul. Gagarina 9, 87-100 Torun; e-mail: pweck@umk.pl

\begin{abstract}
Palaeoslopes of Weichselian sand-bed braided rivers have been reconstructed for two stages of fluvial development in the Torun Basin. (1) The palaeoslope of the 'fossil' fluvial succession (buried under Weichselian tills) was calculated on the basis of the median grain size and the Shields parameter. The hydraulic gradient thus found is comparable with the hydraulic gradient of the present-day river. (2) The second developmental stage of the Torun Basin (as a apart of the Noteć-Warta ice-marginal valley) took place after deglaciation. The slopes of river terraces are a few times lower than those calculated on the basis of the Shields parameter. The palaeoslope of the then river was estimated on the basis of a constant interdependency between the braidplain width, the channel geometry and the grain size. The river gradient that was thus calculated is similar to the measured terrace slope. Palaeoslope estimates in valleys similar to those in the Torun Basin should consider the width of the braidplain.
\end{abstract}

Keywords: palaeoslope, Shields parameter, sand-bed braided river, river terraces, central Poland

\section{Introduction}

Fluvial environments in the geological record are commonly identified on the basis of lithofacies analysis. A complementary method is the palaeohydraulic analysis (Maizels, 1983; Williams 1983; Paola \& Borgman, 1991; Zieliński, 1992; Leclair \& Bridge, 2001; Zieliński \& Van Loon, 2003). The basic palaeohydraulic parameter characterising the energy of a fluvial environment is the river gradient (hydraulic gradient), $S$ [dimensionless], which was formerly also indicated by the term 'energy slope' (Leopold et al., 1964; Schumm, 1977). The river gradient is used as input for palaeohydraulic reconstructions such as the flow velocity.

The value of the hydraulic gradient can be based on topographic measurements of the slope of river terraces, but the value thus found is reliable only if the original terrace surfaces have not been modified later by geomorphological processes such as wind activity (sand-cover formation) and fluvial activity of younger water courses (erosional or depositional remodelling). This method of determining a hydraulic gradient cannot commonly be used for 'fossil' fluvial deposits covered by glacial till, because the present-day surface is built by till younger than the 'fossil' fluvial series. It is consequently difficult to analyse the palaeohydraulic situation in the past quantitatively, or to determine the changes of a river gradient during the evolution of the fluvial system.

The present contribution shows, however, that such an analysis is possible. The data for the study have been taken from Polish alluvial 
Table 1. Parameters characterising the ice-marginal valley terraces $(S=$ measured slope, $W=$ braidplain width $)$ and the corresponding river depth $(H)$ and the average values of the median grain diameter $\left(d_{50}^{\prime}\right)$.

\begin{tabular}{|c|c|c|c|c|c|}
\hline Log no & $\begin{array}{l}\text { Terrace } \\
\text { number }\end{array}$ & $\begin{array}{c}\text { Measured slope } \\
S \text { (dimensionless) }\end{array}$ & $\begin{array}{c}\text { Average value of median } \\
\text { grain diameter } \\
d_{50}^{\prime}(\mu \mathrm{m})\end{array}$ & $\begin{array}{c}\text { Channel depth } \\
H(\mathrm{~m})\end{array}$ & $\begin{array}{l}\text { Braidplain width } \\
\qquad W(\mathrm{~km})\end{array}$ \\
\hline 1 & XI & 0.000103 & 260 & 1.5 & 17.0 \\
\hline 2 & XI & 0.000103 & 295 & 2.0 & 17.0 \\
\hline 3 & $x$ & 0.000077 & 138 & 2.5 & 22.0 \\
\hline 4 & $\mathrm{TT}$ & 0.00013 & 400 & 1.4 & 12.0 \\
\hline 5 & TT & 0.000145 & 1734 & 3.1 & 7.3 \\
\hline 6 & IX & 0.000111 & 511 & 1.7 & 15.0 \\
\hline 7 & IX & 0.000111 & 551 & 1.4 & 13.6 \\
\hline 8 & IX & 0.000111 & 1205 & 2.2 & 13.3 \\
\hline 9 & VIII & 0.000105 & 1028 & 2.2 & 10.5 \\
\hline 10 & VIII & 0.000105 & 443 & 1.5 & 10.5 \\
\hline 11 & VI & 0.000148 & 656 & 1.2 & 9.5 \\
\hline
\end{tabular}

deposits and terraces in the Torun Basin. These are partly older than the Last Glacial Maximum (Nowe Dąbie site, logs 12-13), partly younger (logs 1-11; Table 1). The findings have been compared with the hydraulic and geomorphological data of the present-day South Saskatchewan River (Canada). One of the reasons for the reconstruction of the changes in palaeoslopes of the streams in the Torun Basin is the dependence of the fluvial relief on the oscillations of the rivers' base level.

\subsection{Geological and geographical setting}

The Torun Basin is the eastern part of the Noteć-Warta ice-marginal valley, and belongs to its biggest widenings in the lower Vistula river valley (Fig. 1A). The genesis of the Torun Basin demonstrates erosion and accumulation by meltwaters during the recession of the Weichselian ice sheet. In the Torun Basin a set of eleven river terraces (I-XI) is distinguished (terrace numbering according to Galon, 1961). Terraces VI-XI were originated due to water flow through the Noteć-Warta ice-marginal valley. Vertical changes of the river base level were triggered by the changes in the Vistula course, by the location of the Noteć ice-marginal valley mouth (Galon, 1961; Weckwerth, 2010) and by the changes in the extent of the Weichselian ice sheet, which dammed off the waters of the northern part of the North Sea and the southern Baltic basins (Mojski, 1995; Starkel, 2001). These processes resulted from the recession of the ice sheet at the end of the late Weichselian and from the Vistula waters finding a way from the Płock Basin to the Torun Basin at about 14-15 ka BP (Niewiarowski \& Weckwerth, 2006; Weckwerth, 2006). The flow of Vistula river from the Płock Basin to the Torun Basin occurred first time during the formation of 'transitional' terrace (Weckwerth, 2010).

The evolution of the fluvial relief of the Torun Basin was also influenced by variations in the weight of the overlying ice sheet, which triggered glacial and postglacial isostatic movements (Mojski, 1980; Weckwerth, 2007, 2010). These processes resulted from the oblique course of the Torun Basin axis in relation to the axis of Mid-Polish Anticlinorium. All these factors influenced both the erosional and depositional activity of the sand-bed braided river which flowed in the basin once deglaciation had started. A system of ice-marginal valley terraces of different width and lithology than developed in the Torun Basin (Table 1). These are cut-and-fill terraces. The current terrace widths are smaller than that of the former floodplain (braidplain) due to river incision to a lower level and erosion of earlier developed terraces.

The above-mentioned factors conditioning the evolution of the river system might have 
been active also in the Torun Basin at the end of the middle Weichselian and the beginning of the late Weichselian (Weckwerth, 2009; Weckwerth et al., 2011). At that time, i.e. before the first advance of the Weichselian ice sheet, a river valley existed there, probably an ice-marginal valley. The sand-bed braided river ran to the West. The deposits of this river are presently found below the tills of the Weichselian glaciation, so it is impossible to apply topographic measurements to determine the river gradient. This gradient, indispensable for further quantitative palaeohydraulic analysis of the ancient river, can be determined using the methods described by Paola \& Mohrig (1996) and Dade \& Friend (1998).

\subsection{Comparison with a present-day equivalent}

The main difference between the Weichselian and the post-glacial fluvial systems was the
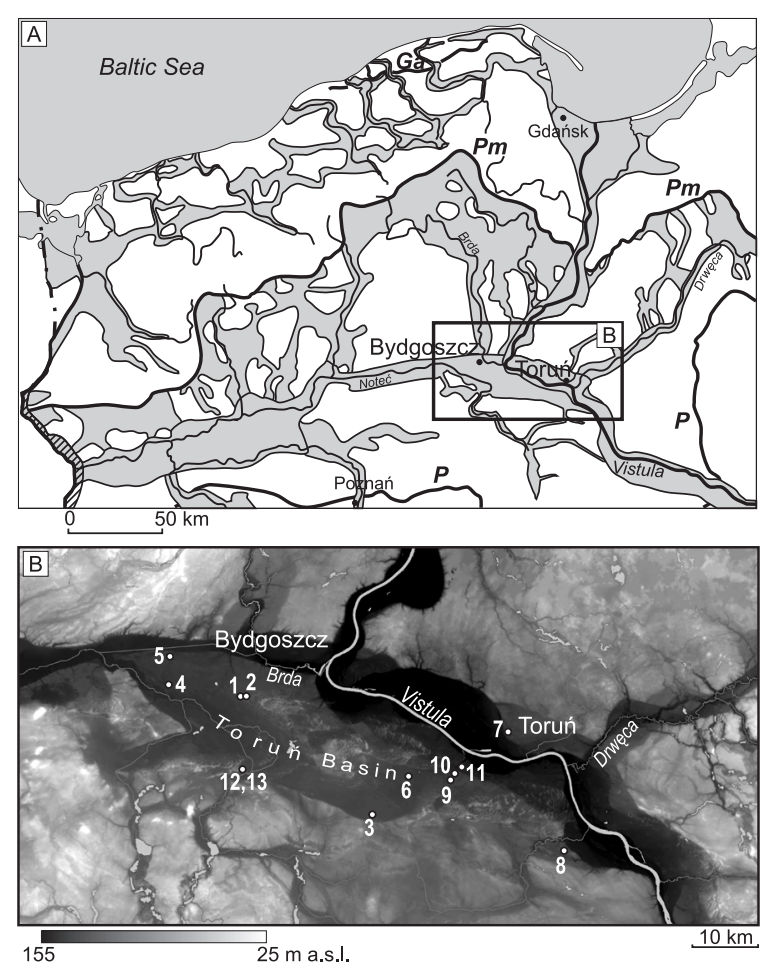

Fig. 1. Location of the study area with sites investigated. A: Fluvial and glaciofluvial deposits in NW Poland. P = maximum extent of the Weichselian ice sheet; Pm, $\mathrm{Ga}=$ recessional stages of the Weichselian ice-sheet retreat; B: Relief of the Torun Basin and the location of the sites investigated $(\operatorname{logs} 1-13)$. higher aggradation ratio before the Last Glacial Maximum (LGM) (Wysota, 2002; Weckwerth, 2009; Weckwerth et al., 2011). Their lithology is similar to the deposits of the South Saskatchewan River (Cant, 1978; Cant \& Walker, 1978). This river has a very low gradient (0.0003); the channel deposits are well sorted and have a mean grain size of $0.3 \mathrm{~mm}$. A similar river gradient can be expected in the case of the ancient river in the Torun Basin.

\subsection{Objectives}

The main objective of the present study was the analysis of the rivers' gradients within the Torun Basin and a comparison with the hydraulic gradient of the present-day river. Both the former and the modern rivers are comparable as regards flow regime and lithofacies characteristics of the channel deposits. Planar and trough cross-bedded sands are common for the sandy braided rivers in the alluvial system that existed before the LGM and the one within the Torun Basin during recession of the ice sheet.

The estimated river gradient $\left(S_{E}\right)$ can differ from the real gradient $(S)$. An important objective when measuring the river gradients was therefore a comparison of the measured slopes of the terrace levels in the Torun Basin $(S)$ with the river palaeogradient $\left(S_{E}\right)$ as calculated for the same terraces on the basis of the channel palaeodepth and the median grain size of the alluvial deposits.

\section{Methods}

The depositional environment was reconstructed on the basis of the structural and textural features of the deposits. The types of lithofacies were determined so as to distinguish the characteristics for the various units representing the fluvial sub-environments (cf. Miall, 1985; Zieliński, 1993, 1998). The grainsize distribution of the gravel/sand fraction of the deposits was determined by sieving at 1-phi intervals, whereas the sand/clay fraction was measured with a laser particle-size analyser (Analysette 22) at 0.25-phi intervals. The 


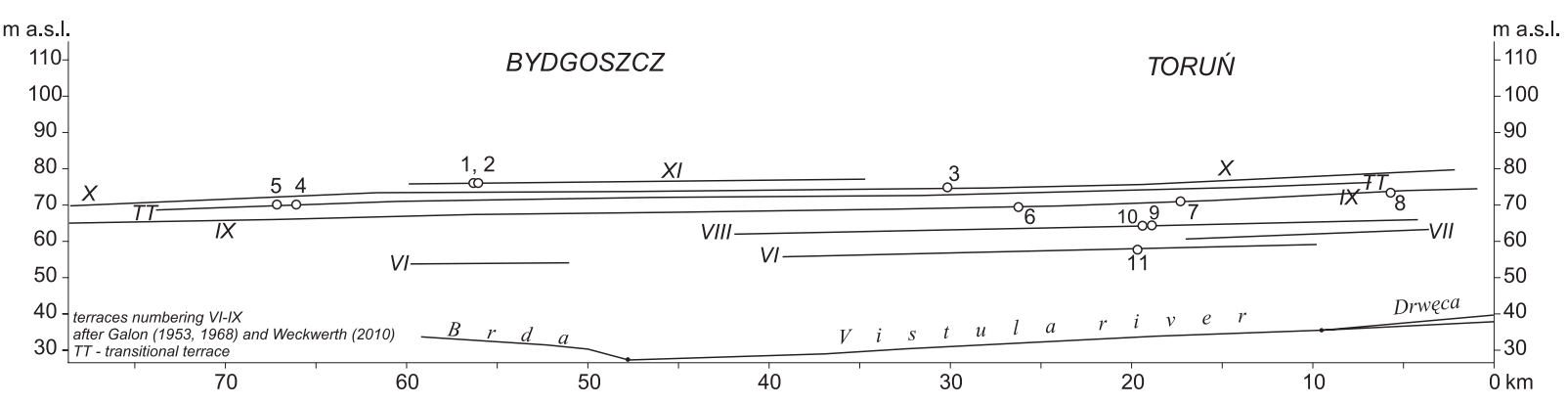

Fig. 2. Longitudinal profile of the terraces of the ice-marginal valley and location of the sites under study.

median grain size, $d_{50^{\prime}}$ has been estimated. The average median value for the entire series of the channel deposits, $d^{\prime}{ }_{50}$, was correlated with the thickness of the individual lithofacies.

The slope of the terrace surface has been determined in the vicinity of each site under study (Figs 1-2; Table 1). In order to determine the river gradient for the fluvial succession (the Nowe Dąbie site; logs 12 and 13 in Fig. 1), which is located below the glacial till, the Du Boy equation $(\tau=\rho g H S)$ and the Shields equation $\left(\theta=\tau / \rho g R d_{50}\right)$ have been used (cf. Paola et al., 1992; Julien \& Wargadalam, 1995; Dade \& Friend, 1998; Dade, 2000; Paola, 2000; Frings, 2008).

The symbols of the parameters (see also the Appendix) are: $\tau=$ bed shear stress $\left[\mathrm{kg} / \mathrm{ms}^{2}\right], \rho$ = water density $\left[\mathrm{kg} / \mathrm{m}^{3}\right], H=$ hydraulic radius (channel depth) [m], $\theta=$ dimensionless Shields parameter, $g=$ gravitational acceleration $(=9.81$ $\left.\mathrm{m} / \mathrm{s}^{2}\right), R=$ relative excess density of sediment particles, $d_{50}=$ median grain size $[\mathrm{m}]$. According to Dade \& Friend (1998), the transport of bedload, suspended load and mixed load (i.e. both bedload and suspended load) in natural rivers is characterised by constant values of the Shields parameter. It depends on the grain size, channel depth and river gradient $\left(\theta=S H / R d_{50}\right)$. The value of the Shields parameter is 0.047 for bedload transport, 1 for mixed load and 10 for suspended load (Komar, 1987; Paola \& Mohrig, 1996; Dade \& Friend, 1998). For calculation of the previous river gradient, one of the above three values was used, depending on the indicator $w / u_{*}$ (where $w_{s}$ is the settling velocity of particles and $u_{*}$ is the friction velocity: Dade, 2000). For the deposits of the ice-marginal valley, the indicator $w / u_{*}$ ranges from 0.09 to 4.76
(Table 2). For the Nowe Dąbie site (logs 12 and 13), $w_{s} / u_{*}=0.34$, thus $\theta \approx 1$.

In order to estimate the river gradient, it is necessary to determine the channel depth, $H$ $[\mathrm{m}]$. In practice it is the depth of the channel when completely filled with water (bankfull depth). $H$ is estimated on the basis of the thickness of the individual lithofacies $S p$ (sand with planar cross-bedding) and $S t$ (sand with trough cross-bedding). For lithofacies $S p$, the flow depth roughly equals the thickness of the $S p$ deposits. If the thickness is insignificant (up to $0.4 \mathrm{~m}$, average $0.15 \mathrm{~m}$ ), the lithofacies can either represent straight-crested sand waves or small transverse bars. These develop under conditions of decreasing depth and energy of the flow and they can form cosets of large transverse channel bars. These bars can be formed by superimposing of smaller bars of the same type (Williams, 1971; Cant, 1978; Cant \& Walker, 1978; Zieliński, 1992). The thicknesses of the $S p$ cosets have been used for estimation of the channel depth $(H)$ when completely filled with water. Transverse bars may also consist of a single large-scale tabular set. The set thickness is similar to the water depth in this case (Williams, 1971; Sauderson \& Jopling, 1980; Mohrig et. al., 2000). During the upper part of the lower-stage flow regime, 3-D dunes also develop (Wiliams, 1971; Cant, 1978; Cant \& Walker, 1978). The flow depth was estimated in such a case to be the five-fold of the thickness of the sets of the trough crossstratified sands (cf. Simons \& Richardson, 1962; Ashley, 1978; Cant, 1978; Leclair \& Bridge, 2001; Prent \& Hickin, 2001). For massive or horizontally stratified sand and gravelly sands, the flow depth was estimated on the basis of the $d_{50}$ value (cf. Williams, 1983; Julien \& Raslan, 1998). 


\section{Results}

The sediments in the ice-marginal valley terraces in the Torun Basin were deposited by a sand-bed braided river. The deposition followed an erosional phase, when the river incised 4-5 $\mathrm{m}$ into the older alluvium (Weckwerth, 2004, 2010). Cross-stratified sands (Sp, St) and gravelly sands (SGP) dominate the fluvial deposits under study (Figs 3-4), while massive sands $(\mathrm{Sm})$ and fine-grained gravel $(\mathrm{Gm})$ are of minor importance. The average values of the median grain size $\left(d^{\prime}{ }_{50}\right)$ of each terrace deposits were estimated on the basis of the thickness of the individual lithofacies. They range from $0.138 \mathrm{~mm}$ to $1.734 \mathrm{~mm}$ (Figs 3-4; Table 1).

The Torun Basin terraces are erosional remnants of Weichselian braidplains. The terrace slopes are considered to represent the braidplain slope, but the braidplain was wider than the present-day terraces. The relation of slopes of the ice-marginal valley terraces to average median grain diameter $\left(d_{50}^{\prime}\right)$ of their deposits allows to distinguish three groups. The transitional terrace and terrace VI show the steepest slopes (0.00014 and 0.00015, respectively), whereas terrace $X$ has the least inclined slope (0.000077); the other terraces have moderate ones (Table 1; Fig. 5). The terrace slope is slightly correlated with the average value of median grain size $\left(d^{\prime}{ }_{50}\right)$ of the deposits (Fig. 5; Table 1) and decreasing values of the terrace slope $(S)$ are clearly correlated with an increase in the width of the ancient braidplain and channel depth (Fig. 6A, C; Table 1). A similar relation of the width of the braidplain $(W)$ is observed in the case of the average values of $d_{50}^{\prime}$. Decreasing braidplain width $(W)$ is correlated with an increasing value of $d_{50}^{\prime}$ (Fig. 6B).

These relationships between the gradient of the ice-marginal valley terraces inspired the present author to compare the measured slopes
Fig. 3. Lithology of terraces XI, $X$ and the transitional terrace.

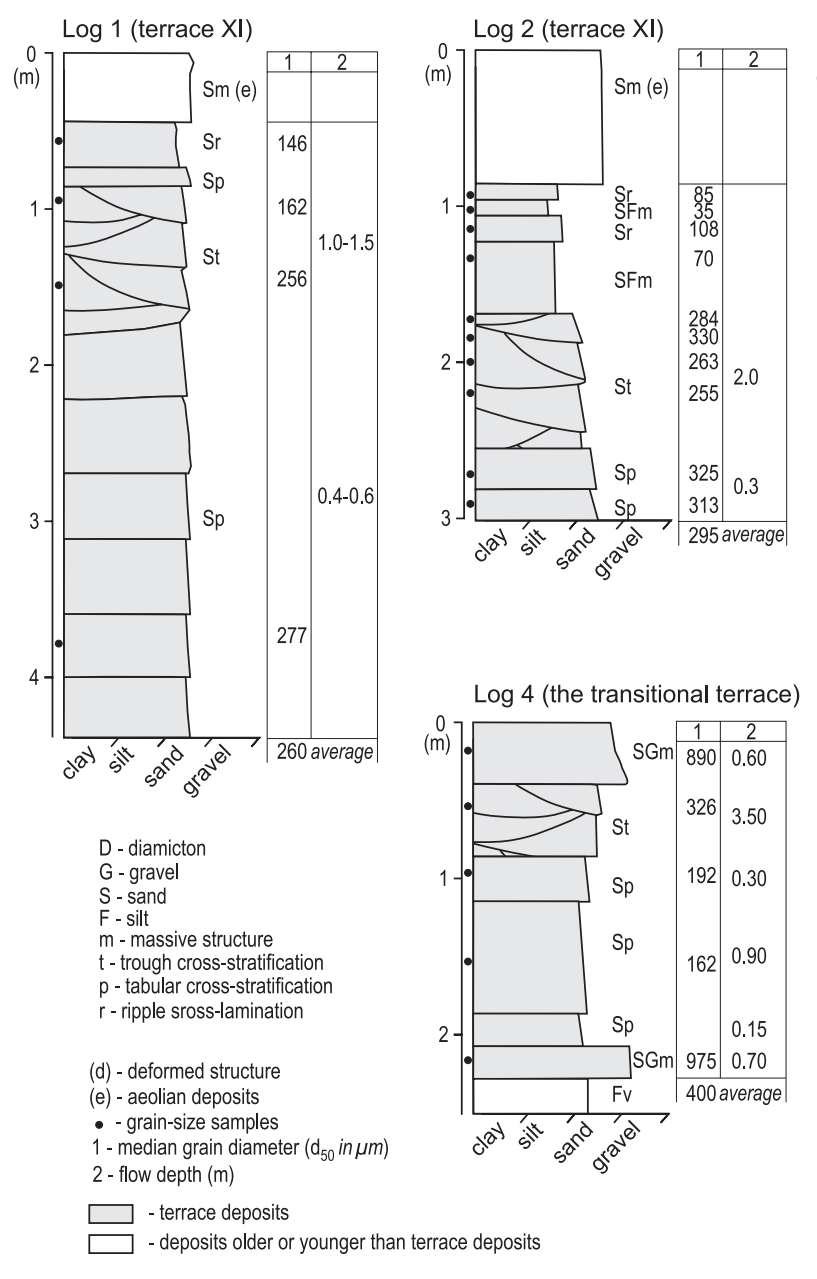

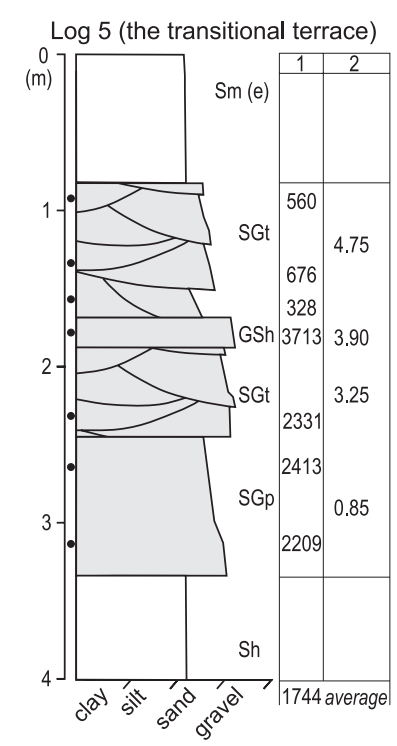



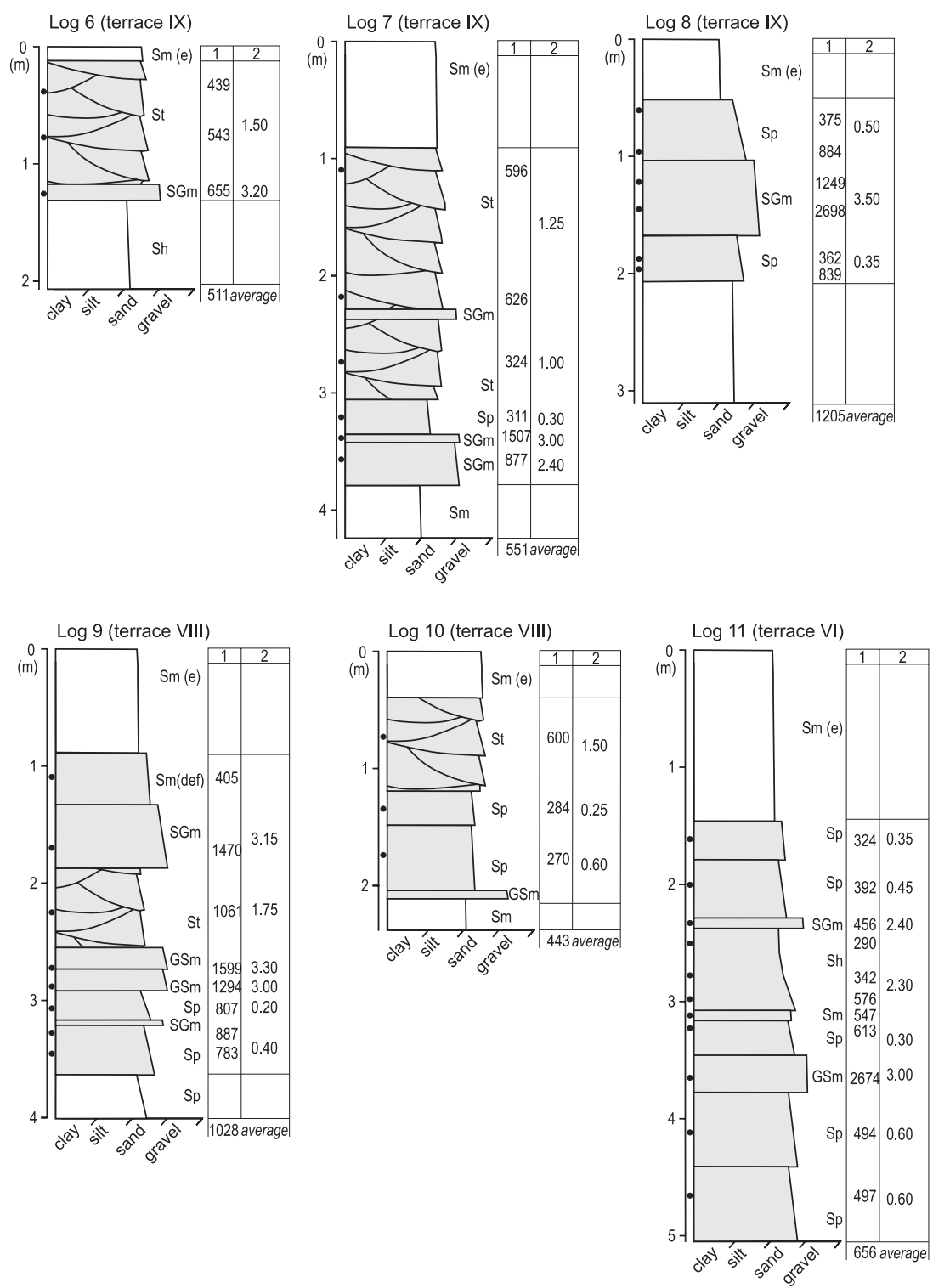

Fig. 4. Lithology of terraces IX, VIII and VI. See Figure 3 for explanations.

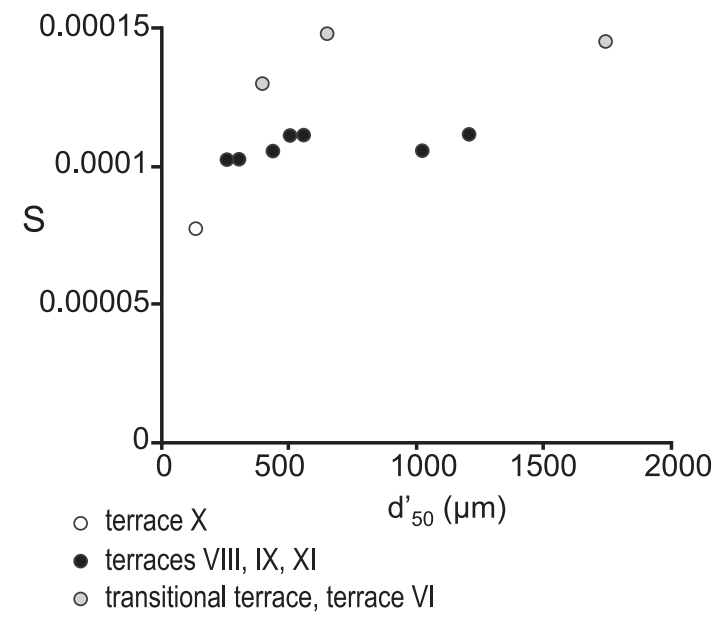

Fig. 5. Three groups of the terraces of the ice-marginal valley distinguished on the basis of the mean values of gradient $S$ in relation to the average value of the median grain size $\left(d^{\prime}{ }_{50}\right)$. of the terrace levels $(S)$ with the values of the river gradient, which were estimated for the same terraces on the basis of the palaeodepth and median grain size $\left(S_{E}\right)$. Due to the gentle slope of the terraces $(S)$, the values of their Shields parameter $(\theta)$ are much lower than 1 , averaging 0.28 (Table 2 ). Thus, a constant value was considered reasonable for the Shields parameter, $\theta_{E^{\prime}}$ it depends on the value of the ratio $w / u_{*}$. The estimated river gradient, $S_{E}$, differs from the measured slope, $S$ (Table 2). In the case of the deposits of a mixed-load river type $\left(\theta_{E}=1\right)$, the differences are smaller than in the case of a bedload or suspended load river. Earlier research of the terraces in the Torun Basin (Niewiarowski \& Tomczak, 1969; Weckwerth, 
2004, 2010) indicates that they consist mainly of sand. It is therefore reasonable to accept that $\theta_{E}$ $=1$ when estimating their palaeoslopes (Table 2). These estimates of $S_{E}$ are much more similar to the measured gradient, $S$.

Several relationships exist between the width of the ancient braidplain $(W)$ and other parameters $\left(S, d^{\prime}{ }_{50}^{\prime} H\right)$ (Fig. 6). The strongest correlation is found between the gradient, $S$, and the width of the braidplain, $W(W=$ $0.034 S^{-1.41}$ ). It also means that $S_{E}$ (calculated for $\left.\theta_{E}=1\right)$ depends on the width of the braidplain $\left(W=840 S_{E}^{-0.36}\right)$ (Fig. 7). Consequently, the estimates of the palaeoslopes in valleys similar to the Torun Basin, i.e. with systems of cutand-fill terraces, should consider the width of the braidplain $(W)$. Thus, the estimated river gradient is $S_{W}=8 \times 10^{-4} S_{E}^{0.26}$. The value of the calculated river gradient, $S_{W^{\prime}}$ is similar to the measured terrace slope (Table 2).

Another fluvial succession was noted at the Nowe Dąbie site in the south-western part of the Torun Basin (logs 12 and 13 in Fig. 1; Fig. 8). It was deposited by a sand-bed braided river before the main stage of the Weichselian glaciation. Thus, fluvial deposits exist under the tills (Weckwerth, 2009; Weckwerth et al., 2011). The mentioned succession fills the buried valley.

Lithofacies analysis of the deposits at the Nowe Dąbie site shows a distinct similarity to the lithofacies of the sand flat braided river described by Cant (1978) and Cant \& Walker (1978). The average values of the median grain size $\left(d_{50}^{\prime}\right)$ of the various deposits in logs 12 and 13 are 0.198 and $0.229 \mathrm{~mm}$ respectively (Fig. 8). The channel depth was estimated on the basis of the lithofacies which fill up the buried river channel. They reflect a waning flood stage. The depth of the river channel was calculated to be $2.3 \mathrm{~m}$ (Fig. 8, log. 13). Roughly similar values of the channel depth $(2.0 \mathrm{~m}$ and $2.2 \mathrm{~m})$ were estimated from the analysis of the set thickness of the trough cross-bedded sands which fill up the mentioned channel. The channel depth was also calculated on the basis of the thickness of the sets of large-scale tabular cross-bedded sands (Fig. 8, log. 12), with $2.1 \mathrm{~m}$ as the result. The average median grain size of the litho-
A

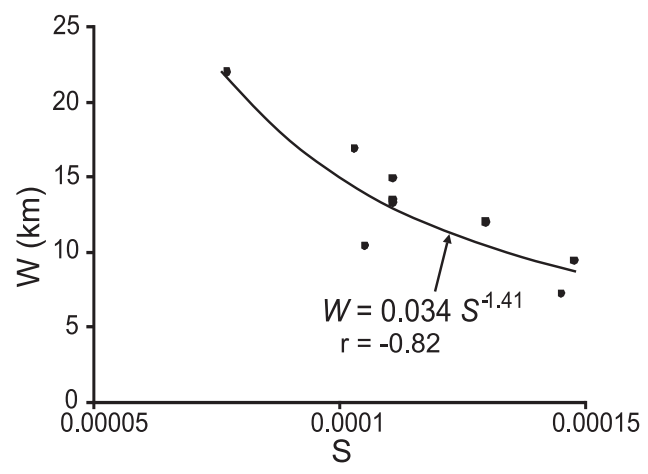

B

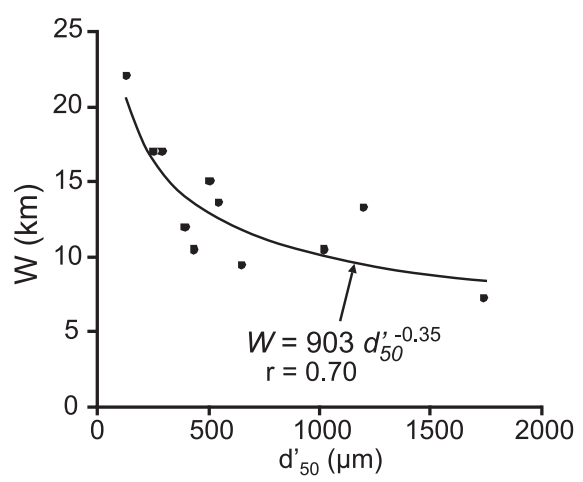

C

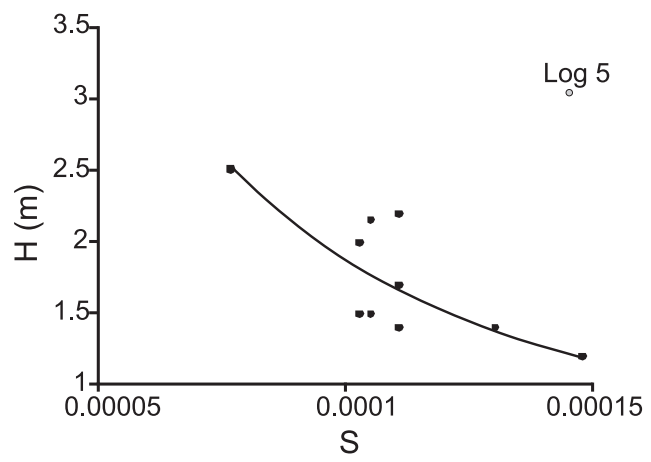

Fig. 6. Relations between the river gradient $(S)$, the average value of the median grain size $\left(d^{\prime}{ }_{50}\right)$, channel depth $(H)$ and braidplain width $(W)(\mathrm{r}=$ Pearson correlation coefficient).

facies which fill up the river channel is 0.274 $\mathrm{mm}$, while that of the large-scale tabular sets is $0.264 \mathrm{~mm}$. This means that the values of the indicator $w / u_{*}$ are 0.36 and 0.33 , respectively. The estimate of the gradient of the ancient river was based on the value of the Shields parameter, $\theta_{E}=1$ (mixed-load transport). The calculated values of the palaeoslope are 0.00037 and 0.00026 , respectively, which means that the average value for the entire fluvial succession is 0.00031 . This value is similar to that of the 
Table 2. Values of the Shields parameter $(\theta)$ (estimated on the basis of $S, d^{\prime}{ }_{50}$ and $H$ ) and estimated slope $\left(S_{E}\right)$ for a constant value of the Shields parameter $\left(\theta_{E}\right)$. The palaeoslope $\left(S_{W}\right)$ has been estimated on the basis of the width $(W)$ of the ancient braidplain.

\begin{tabular}{|c|c|c|c|c|c|c|c|}
\hline $\begin{array}{l}\text { Log } \\
\text { no }\end{array}$ & $\begin{array}{l}\text { Terrace } \\
\text { number }\end{array}$ & $\begin{array}{l}\text { Measured } \\
\text { slope } \\
S\end{array}$ & $\begin{array}{c}\text { Shields } \\
\text { parameter } \\
\theta \\
\text { (mean } 0.28 \text { ) }\end{array}$ & $w_{s} / u_{*}$ & $\begin{array}{c}\text { Constant Shields } \\
\text { parameter } \\
\theta_{E}\end{array}$ & $\begin{array}{c}\text { Estimated river } \\
\text { gradient } \\
S E \\
\text { (in brackets } \\
S E \text { for } \theta_{E}=1 \text { ) }\end{array}$ & $\begin{array}{c}\text { Estimated river } \\
\text { gradient } \\
S W \\
\left(\theta_{E}=1\right)\end{array}$ \\
\hline 1 & XI & 0.000103 & 0.36 & 0.33 & 1 & 0.00034 & 0.000101 \\
\hline 2 & XI & 0.000103 & 0.42 & 0.41 & 1 & 0.00030 & 0.000967 \\
\hline 3 & $x$ & 0.000077 & 0.84 & 0.09 & $10(1)$ & $0.00091(0.00011)$ & 0.000075 \\
\hline 4 & TT & 0.000130 & 0.27 & 0.74 & 1 & 0.00057 & 0.000115 \\
\hline 5 & $\mathrm{TT}$ & 0.000145 & 0.15 & 4.76 & $0.047(1)$ & $0.00004(0.00114)$ & 0.000137 \\
\hline 6 & IX & 0.000111 & 0.22 & 1.15 & 1 & 0.00060 & 0.000116 \\
\hline 7 & IX & 0.000111 & 0.17 & 1.31 & 1 & 0.00079 & 0.000124 \\
\hline 8 & IX & 0.000111 & 0.12 & 3.83 & $0.047(1)$ & $0.00004(0.00110)$ & 0.000136 \\
\hline 9 & VIII & 0.000105 & 0.13 & 3.26 & $0.047(1)$ & $0.00004(0.00095)$ & 0.000131 \\
\hline 10 & VIII & 0.000105 & 0.22 & 0.89 & 1 & 0.00059 & 0.000116 \\
\hline 11 & VI & 0.000148 & 0.16 & 1.75 & 1 & 0.00109 & 0.000136 \\
\hline
\end{tabular}

South Saskatchewan River (0.0003: Cant, 1978; Cant \& Walker, 1978).

\section{Discussion}

The terraces of the Torun Basin evolved due to both erosion and accumulation of sand-bed braided rivers, which gathered waters from the both north (meltwater) and the south (e.g. the Vistula River and the upper reach of the Noteć River). The geological structure of these terraces indicates that the fluvial forms were dominated by transverse bars, which at some

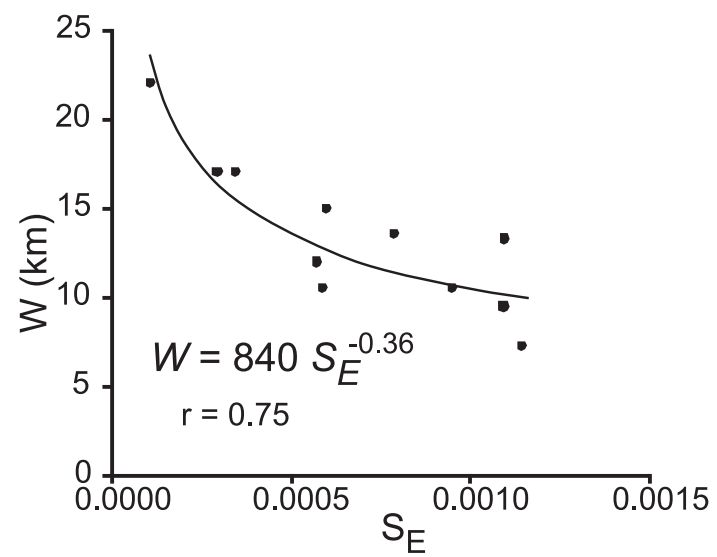

Fig. 7. Relation between the ancient braidplains width $(W)$ and the estimated river gradient $\left(S_{E}\right)(\mathrm{r}=$ Pearson correlation coefficient). places were cut by 3-D dunes in the thalweg. The river in the ice-marginal valley was depositional rather than erosional, and the accumulation rate increased during the formation of the lower terrace. The relationship between the grain size $\left(d^{\prime}{ }_{50}\right)$ of the terrace deposits and the slope of the terrace surfaces $(S)$ supports the hypothesis by Henderson (1961) that the river gradient increases together with the median grain size of the sediment (Fig. 7). The braidplain became narrower (i.e. the number of channels on the braidplain decreased) with an increase in the terrace slope (Fig. 6A; Table 1). These relationships between the gradient $S$, the median grain size of the sediment and the terrace width (braidplain width) $W$, resulted from the degree of stability of the river channel as a consequence of the available flow energy (cf. Parker, 1976; Julien \& Wargadalam, 1995; Lee \& Julien, 2006). The increasing hydraulic gradient, which also meant an increase in flow energy (in practice an increase in $d^{\prime}{ }_{50}$ ), is reflected by the decrease in both channel depth and braidplain width (Figs 6, 7). This supports the relationships mentioned by Dade (2000) between the mentioned parameters. In accordance with Dade (2000), an increase in the available grain size causes a decrease in channel width and an increase in the bed friction (cf. Mackin, 1948). In the case of the Torun Basin, part of the river energy was used for downward incision and 
Fig. 8. Lithology of the fluvial series deposited before the Last Glacial Maximum at the Nowe Dąbie site (logs 12 and 13), representing sandbed braided rivers (sand flat braided river lithotype).

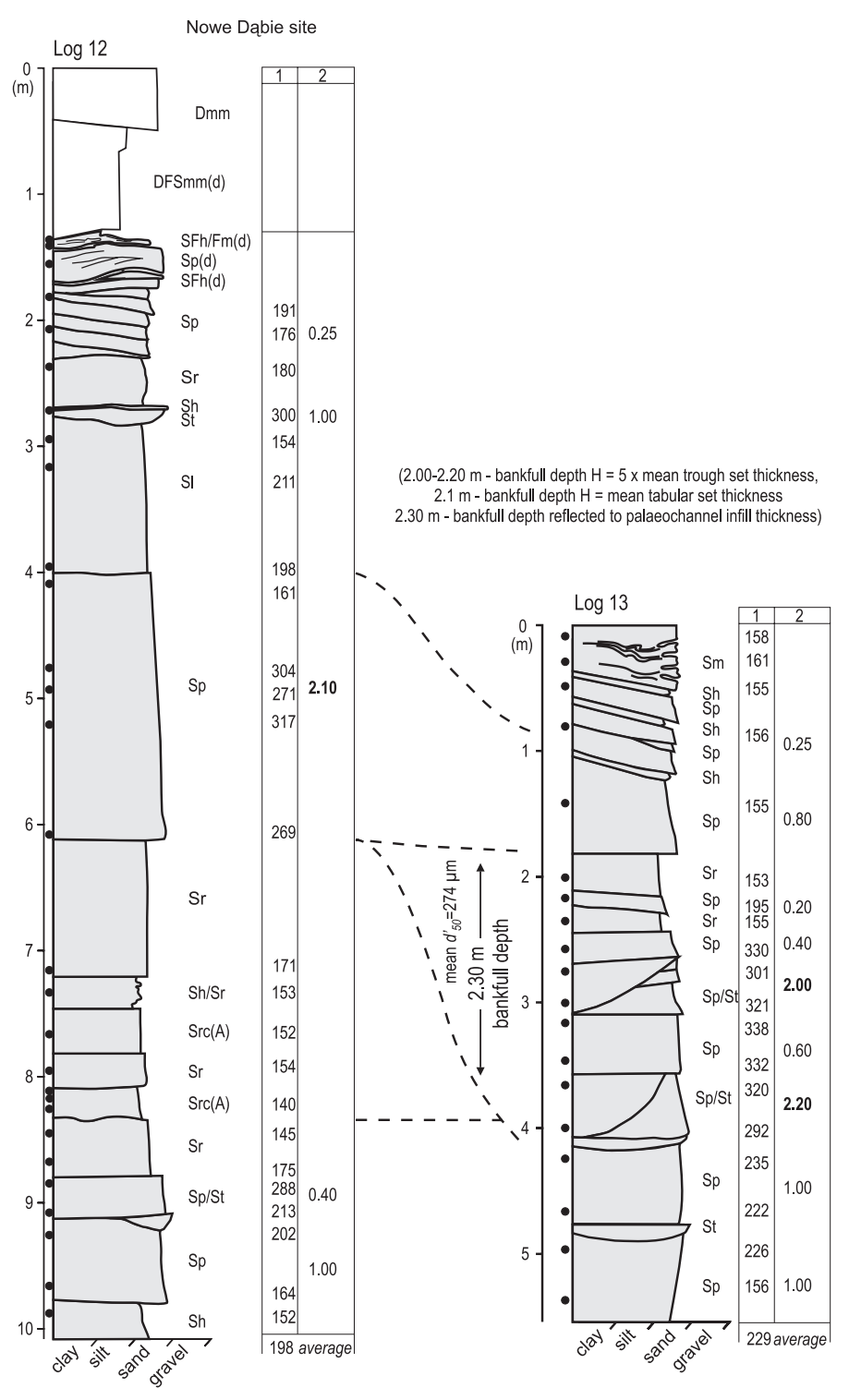

lateral erosion. This might explain why the values of the Shields parameter, $\theta$, are lower than 1 ( 0.28 on average). On the other hand, $\theta$ is close to $1(\theta=0.85)$ for terrace $X$, the deposits on which are comparable with those of a lowenergy distal outwash plain (Zieliński, 1993; Zieliński \& Van Loon, 2003). The high value of the Shields parameter for terrace $X$ results from the small average value of the median grain size, $d_{50}^{\prime}$ (Tables 1-2). In the case of other terraces in the Torun Basin, the differences between $\theta$ and $\theta_{E}=1$ may result from coarser sediments and the fact that some energy was lost by erosional activity within the channel. The slopes of the terraces $(S)$ within the Torun Basin are too gentle if the grain size of the sediments is taken into account. The estimated river gradient, $S_{E}$, based on the constant $\theta_{E}=1$ (Table 2) is larger than the measured slope, $S$. As both $S_{E}$ and $S$ show a similar relationship with the width of the braidplain $(W)$, the estimated channel gradient is estimated (based on braidplain width) as $S_{W}=8 \times 10^{-4} S_{E}^{0.26}$ (Fig. 7).

The interrelationship between the palaeoflow depth, gradient and width of the braidplain on the one hand, and the median grain size of the fluvial sediments on the other hand shows that the fluvial forms and their features (cut-and-fill terraces, braidplain slope and width, bedforms) adjusted to the changes of the discharge into the ice-marginal valley, the height of the base level and neotectonic move- 
ments (Weckwerth, 2010). Initially (formation of terrace XI and X), the energy of the river was low. The dominant lithofacies of tabular crossbedded sands, the secondary role of trough cross-bedded sands, the fine grain size $\left(d^{\prime}{ }_{50}\right)$ of the sediments and gentle slope $(S)$ of the terraces indicate a distal part of the outwash (Zieliński, 1993; Zieliński \& Van Loon, 2003). Braided channels in the distal part of outwashes are characterised by frequently floods, the occurrence of transverse bars and a relatively wide braidplain. The key moments for the development of the ice-marginal valley were (1) when the water of the Vistula found its way into the Torun Basin from the south Płock Basin, which took place during the formation of the transitional terrace, and (2) when the meltwater discharge ceased (Weckwerth, 2004, 2010). The sudden inflow of the Vistula water from the South is reflected by a higher river gradient and a coarser median grain size than in the older terraces $\mathrm{X}$ and XI.

The estimated basic parameters of the channel geometry and palaeohydraulic conditions for the buried fluvial succession are compared with those of present-day rivers and their deposits. The succession at the Nowe Dąbie site (logs 12 and 13) shows similar dimensions of dunes and transverse bars, and a similar average grain size $(0.3 \mathrm{~mm})$ and channel slope $(0.0003)$ as the South Saskatchewan River (Cant, 1978; Cant \& Walker, 1978), which is the largest river in the southern Canadian prairies, with a valley depth of about $30 \mathrm{~m}$. The South Saskatchewan River forms a braided fluvial system with an average discharge of $275 \mathrm{~m}^{3} / \mathrm{s}$. The maximum discharge is controlled by snow melt and precipitation.

\section{Conclusions}

The palaeoslopes of ancient sand-bed braided rivers have been reconstructed for two stages of fluvial development in the Torun Basin. The first phase, was characterised by intensive fluvial accumulation in front of the Weichselian ice sheet. Nowadays these fluvial sediments are buried under Weichselian tills, but the river gradient could be reconstructed by quantitative palaeohydraulic analysis based on an estimate of the Shields parameter. It was thus found that the palaeoslope was 0.0003 .

The second stage of the fluvial development in the Torun Basin took place after deglaciation. The system of ice-marginal valley terraces which developed at the time was the reaction of the river to the changing environmental conditions (climate, discharge, base level height and catchment area). The measured values of the river channel gradient are a few times lower, namely 0.00008-0.00015, than those calculated on the basis of the Shields parameter (0.0001-0.001). A fairly reliable estimate is possible, however, because a constant interdependency exists between the channel geometry and the grain size of the deposited sediments on the one hand, and the width of the braidplain on the other hand. Narrowing of the river braidplain in the Torun Basin, accompanied by a variable but low-angle slope, occurred during river channel erosion in a non-cohesive bedding. The sand-bed braided river reached a new equilibrium state, at a lower elevation of the narrower braidplain. This process resulted in the transport of coarser particles. The palaeoslope calculation based on the median grain size $\left(d_{50}\right)$ and the Shields parameter can therefore give a too high value.

The estimated hydraulic gradient of the buried fluvial succession is comparable with that of the present-day South Saskatchewan River, which is characterised by similar channel forms and bedforms. If the gradient values found by estimation and measuring are significantly different, the formula $S_{W}=8 \times 10^{-4} S_{E}{ }^{0.26}$ can be applied to calculate the proper value of the hydraulic gradient.

\section{References}

Ashley, G.M., 1978. Bedforms in the Pitt River, British Columbia. [In:] A.D. Miall (Ed.): Fluvial sedimentology. Canadian Society of Petroleum Geology, Calgary, 88-104.

Cant, D.J., 1978. Bedforms and bar types in the South Saskatchewan River. Journal of Sedimentary Petrology 48, 1321-1330.

Cant, D.J. \& Walker, R.G., 1978. Fluvial processes and facies sequences in the sandy braided South Saskatchewan River, Canada. Sedimentology 25, 625-648. 
Dade, W.B., 2000. Grain size, sediment transport and alluvial channel pattern. Geomorphology 35, 119-126.

Dade, W.B. \& Friend, P.F., 1998. Grain size, sedimenttransport regime and channel slope in alluvial rivers. Journal of Geology 106, 661-675.

Frings, R.M., 2008. Downstream fining in large sand-bed rivers. Earth-Science Reviews 87, 39-60.

Galon, R., 1961. Morphology of the Noteć-Warta (or TorunEberswalde) ice marginal streamway. Prace Geograficzne IGiPZ PAN 29, 129 pp.

Henderson, F.M., 1961. Stability of alluvial channels. Journal of the Hydraulics Division 87, 109-138.

Julien, P.Y. \& Raslan, Y., 1998. Upper-regime plane bed. Journal of Hydraulic Engineering 124, 1086-1096.

Julien, P.Y. \& Wargadalam, J., 1995. Alluvial channel geometry: theory and applications. Journal of Hydraulic Engineering 121, 312-325.

Komar, P.D., 1987. Selective grain entrainment by a current from a bed of mixed sizes: a reanalysis. Journal of Sedimentary Petrology 57, 203-211.

Leclair, S.Z. \& Bridge, J.S., 2001. Quantitative interpretation of sedimentary structures formed by river dunes. Journal of Sedimentary Research 71, 713-716.

Lee, J.S. \& Julien, P.Y., 2006. Downstream hydraulic geometry of alluvial channels. Journal of Hydraulic Engineering 132, 1347-1352.

Leopold, L.B., Wolman, M.G. \& Miller J.P., 1964. Fluvial processes in geomorphology. W. H. Freeman and Company, San Francisco and London, 522 pp.

Mackin, J.H., 1948. Concept of the graded river. Geological Society of America Bulletin 59, 463-512.

Maizels, J.K., 1983. Palaeovelocity and palaeodischarge determination for coarse gravel deposits. [In:] K.J. Gregory (Ed.): Background to palaeohydrology. John Wiley \& Sons, New York, 101-139.

Miall, A.D., 1985. Architectural-element analysis: a new method of facies analysis applied to fluvial deposits. Earth-Science Reviews 22, 261-308.

Mohrig, D., Heller, P.L., Paola, C. \& Lyons, W.J., 2000. Interpreting avulsion from ancient alluvial sequences: Guadalope-Matarranya system (northern Spain) and Wasatch Formation (western Colorado). Geological Society of America Bulletin 112, 1787-1803.

Mojski, J.E., 1980. Budowa geologiczna i tendencje rozwoju doliny Wisły [Geological structure and development tendency of the Vistula valley]. Przeglad Geologiczny 6, 332-334.

Mojski, J.E., 1995. An outline of the evolution of the Southern Baltic area at the end of the last glaciation and the beginning of Holocene. Biuletyn Peryglacjalny 34, 167-176.

Niewiarowski, W. \& Tomczak, A., 1969. Morfologia i rozwój rzeźby obszaru miasta Torunia i jego okolic [Morphology and relief development of the town area and vicinity of Toruń]. Zeszyty Naukowe UMK, Geografia 6, 39-89.

Niewiarowski, W. \& Weckwerth, P., 2006. Geneza i rozwój rzeźby terenu [Genesis and relief development]. [In:] L. Andrzejewski, P. Weckwerth \& S. Burak (Eds): Toruń i jego okolice, monografia przyrodnicza [Torun and its surroundings, natural monograph]. UMK, Torun, 65-98.

Paola, C., 2000. Quantitative models of filling. Sedimentology 47, 121-178.

Paola, C. \& Borgman, L., 1991. Reconstructing random topography from preserved stratification. Sedimentology 38, 553-565.

Paola, C., Heller, P.L. \& Angevine, C.L., 1992. The largescale dynamics of grain-size variation in alluvial basins, 1: Theory. Basin Research 4, 73-90.

Paola, C. \& Mohrig, D., 1996. Palaeohydraulics revisited: palaeoslope estimation in coarse-grained braided rivers. Basin Research 8, 243-254.

Parker, G., 1976. On the cause and characteristic scales of meandering and braiding. Journal of Fluid Mechanics 76, 457-480.

Prent, M. \& Hickin, E.J., 2001. Annual regime of bedforms, roughness and flow-resistance, Lillooet River, British Columbia. Geomorphology 41, 369-390.

Sauderson, H.C. \& Jopling, A.V., 1980. Palaeohydraulics of a tabular, cross-stratified sand in the Brampton Esker, Ontario. Sedimentary Geology 25, 169-188.

Schumm, S.A., 1977. The fluvial system. John Wiley \& Sons, New York, 338 pp.

Simons, D.B. \& Richardson, E.V., 1962. Resistance to flow in alluvial channels. Transactions of the American Society of Civil Engineers 127, 927-954.

Starkel, L., 2001. Historia doliny Wisły od ostatniego zlodowacenia do dziś [Evolution of the Vistula river valley since the last glaciation till present]. Monografie 2, Polish Academy of Sciences, Warszawa, 263 pp.

Weckwerth, P, 2007. Późnovistuliański rozwój sieci rzecznej w rejonie Kotliny Toruńskiej na tle struktur starszego podłoża [Development of rivers network in the Late Vistulian period in the Torun Basin region on the background of older bottom tectonic structures]. Stupskie Prace Geograficzne 4, 143-156.

Weckwerth, P., 2004. Morfogeneza wybranych obszarów Kotliny Torunskiej a problem jej roli w układzie hydrograficznym podczas górnego plenivistulianu [Morphogenesis of some areas in the Torun Basin and their role in the hydrographic network during the late Plenivistulian]. Ph.D. thesis Torun University, 168 pp.

Weckwerth, P., 2006. Problem bifurkacji Wisły pod Fordonem (Bydgoszcz) na tle ewolucji Kotliny Toruńskiej pod koniec plenivistulianu [The problem of bifurcation flow of the Vistula River at Fordon (Bydgoszcz) on the background of the Torun Basin evolution in the end of Plenivistulian]. Przeglad Geograficzny 78, 47-68.

Weckwerth, P., 2009. Środowisko depozycji fluwialnej w stadiale głównym zlodowacenia Wisły - stanowisko Nowe Dąbie, południowo-zachodnia część Kotliny Toruńskiej [Fluvial depositional environment of the Main Stadial of the Weichselian Glaciation - Nowe Dąbie pit, SW part of Torun Basin]. [In:] M. PisarskaJamroży \& Z. Babiński (Eds): Plejstoceńskie środowiska sedymentacyjne Pojezierza Pomorskiego [Pleistocene sedimentary environments of the Pomeranian Lake District]. Wydawnictwo UKW, Bydgoszcz, 90-99. 
Weckwerth, P., 2010. Evolution of the Torun Basin in the Late Weichselian. Landform Analysis 14, 57-84.

Weckwerth, P., Przegiętka, K., Chruścińska, A., Woronko, B. \& Oczkowski, H.L., 2011. Age and sedimentological features of fluvial series in the Torun Basin and the Drwęca Valley (Poland). Geochronometria 38, 397-412.

Williams, G.P., 1971. Flood deposits of the sand-bed ephemeral streams of central Australia. Sedimentology 17, 1-40.

Williams, G.P., 1983. Paleohydrological methods and some examples from Swedish fluvial environments. I. Cobble and boulder deposits. Geografiska Annaler 65A, 227-243.

Wysota, W., 2002. Stratygrafia i środowiska sedymentacji zlodowacenia wisły w południowej części dolnego Powiśla [Stratigraphy and sedimentary environments of the Weichselian glaciation in the southern part of the Lower Vistula region]. Nicolas Copernicus University, Torun, $144 \mathrm{pp}$.

Zieliński, T., 1992. Proglacial valley facies of the Silesian Upland - genetic factors and their sedimentological effects. Geologia Sudetica 26, 83-118.
Zieliński, T., 1993. Sandry Polski pótnocno-wschodniej - osa$d y$ i warunki sedymentacji [Outwash plains of NE Poland - sediments and depositional processes]. Silesian University, Katowice, 96 pp.

Zieliński, T, 1998. Litofacjalna identyfikacja osadów rzecznych [Lithofacial identification of alluvial sediments]. [In:] E. Mycielska-Dowgiałło (Ed.): Struktury sedymentacyjne $i$ postsedymentacyjne w osadach czwartorzędowych i ich wartość interpretacyjna [Sedimentary and postsedimentary structures in Quaternary sediments and their value for interpretation]. Warsaw University Press, Warszawa, 195-257.

Zieliński, T. \& Van Loon, A.J., 2003. Pleistocene sandur deposits represent braidplains, not alluvial fans. Boreas 32, 590-611.

Appendix: symbols used

\begin{tabular}{|c|c|c|}
\hline Symbol & Description & Unit \\
\hline$d_{50}$ & median grain diameter & $\mathrm{L}$ \\
\hline$d_{50}^{\prime}$ & average value of median grain diameter & $\mathrm{L}$ \\
\hline$g$ & gravitational acceleration & $\mathrm{LT}^{-2}$ \\
\hline$H$ & hydraulic radius (channel depth) & $\mathrm{L}$ \\
\hline$R$ & relative excess density of sediment particles & \\
\hline$S$ & measured braidplain/terrace slope (hydraulic river gradient) & \\
\hline$S_{E}$ & estimated river gradient for a constant value of the Shields parameter & \\
\hline$S_{W}$ & estimated river gradient in relation to the width $(W)$ of the ancient braidplain & \\
\hline$u_{*}$ & friction velocity & $\mathrm{LT}^{-1}$ \\
\hline$W$ & ancient braidplain width & $\mathrm{L}$ \\
\hline$w_{s}$ & settling velocity of particles & $\mathrm{LT}^{-1}$ \\
\hline$\rho$ & density & $\mathrm{ML}^{-3}$ \\
\hline$\theta$ & Shields parameter estimated on the basis of $S, d_{50}^{\prime}$ and $H$ & \\
\hline$\theta_{E}$ & constant value of Shields parameter in relation to the transport regime & \\
\hline$\tau$ & bed shear stress & $\mathrm{ML}^{-1} \mathrm{~T}^{-2}$ \\
\hline
\end{tabular}

